\title{
Melanoma of the Ciliary Body and Choroid pT2c TNM Finding v7
}

National Cancer Institute

\section{Source}

National Cancer Institute. Melanoma of the Ciliary Body and Choroid pT2C TNM Finding v7. NCl Thesaurus. Code C88694.

Tumor size category 2 without ciliary body involvement but with extraocular extension less than or equal to $5 \mathrm{~mm}$ in diameter. (from AJCC 7th Ed.) 